\title{
A comparative study: use of a Brain-computer Interface (BCI) device by people with cerebral palsy in interaction with computers
}

\author{
REGINA O. HEIDRICH ${ }^{1}$, EMELY JENSEN ${ }^{1}$, FRANCISCO REBELO ${ }^{2}$ and TIAGO OLIVEIRA ${ }^{2}$
}

${ }^{1}$ Pró-reitoria de Pesquisa e Inovação, Universidade Feevale, Rodovia RS-239, 2755, 93352-000 Novo Hamburgo, RS, Brasil

${ }^{2}$ Faculdade de Motricidade Humana, Universidade Técnica de Lisboa, Estrada da Costa, 1499-002 Cruz Quebrada, Portugal

Manuscript received on October 17, 2013; accepted for publication on January 19, 2015

\begin{abstract}
This article presents a comparative study among people with cerebral palsy and healthy controls, of various ages, using a Brain-computer Interface (BCI) device. The research is qualitative in its approach. Researchers worked with Observational Case Studies. People with cerebral palsy and healthy controls were evaluated in Portugal and in Brazil. The study aimed to develop a study for product evaluation in order to perceive whether people with cerebral palsy could interact with the computer and compare whether their performance is similar to that of healthy controls when using the Brain-computer Interface. Ultimately, it was found that there are no significant differences between people with cerebral palsy in the two countries, as well as between populations without cerebral palsy (healthy controls).
\end{abstract}

Key words: Brain-computer Interface (BCI), cerebral palsy, cognitive ergonomics, interaction.

\section{INTRODUCTION}

This article presents a comparative study among people with cerebral palsy and healthy controls, of various ages, using a Brain-computer Interface (BCI) device. The study was conducted with people with cerebral palsy and healthy controls from Portugal and Brazil. A Brain-computer Interface (BCI) allows a person to transfer commands directly to a computer. Instead of using a keyboard, mouse or other input device, the user of this interface simply sends commands via brain waves and the computer responds to them.

People with cerebral palsy, who have their cognitive function preserved, but are unable

Correspondence to: Regina de Oliveira Heidrich

E-mail: RHeidrich390@gmail.com to communicate or move, or both, require technological learning aids. The use of learning objects may involve concepts and knowledge through experimentation practices which would not otherwise be possible. In this manner, through the use of learning objects it is possible to simulate educational situations, thus facilitating the process of school inclusion for these people. Therefore, it is clear that new techniques should be designed within accessibility guidelines, so as to ensure more inclusive digital environments. The term "learning object" generally applies to educational materials designed, and built in small sets, to maximize learning situations with the use of the resource. The basic idea behind them is that the objects are like the blocks with which the learning context is to be built. The IEEE Learning 
Technology Standards Committee (2002) defines it even further: according to this institution, learning objects are "any entity, digital or nondigital, that can be used or re-used or referenced during technology-supported learning". An environment, in learning objects, is a software that has a goal, and in which the student makes decisions that interact with the actions of the interaction environment, resulting in a new environment, with different conditions. Thus, new learning proposals seek to provide learning scenarios that encourage the development of intellectual autonomy and this is achieved through learning processes that promote reasoning and collective problem-solving (Barros, 1994). Learning objects in the form of games present themselves as assistive technologies that contributes applications geared at teaching.

Assistive Technology is any item, piece of equipment or product system, whether purchased commercially or developed with craftsmanship, whether mass-produced, modified or tailor-made, that is used to increase, maintain or improve the skills of people with functional limitations, whether these limitations are physical or sensory. It can be simple or complex, depending on the materials and the technology used.

The concept of assistive technology is considered to be far-reaching, and it can play a crucial part in the promotion of human rights, as it grants people with disabilities the opportunity to achieve autonomy and independence in several aspects of their lives (SDHPR 2009).

Cerebral palsy (CP) is a disorder of posture and movement resulting from an injury to the immature brain during the pre-, peri or postnatal periods (Finnie 2000, Schwartzman 2004, Mundkur and Sankar 2005, Geralis 2007). In 2007, the Executive Committee for the Definition of Cerebral Palsy formulated a definition that describes cerebral palsy as a group of permanent disorders in the development of posture and movement, attributed to non-progressive disorders that take place during fetal or infant development. The motor disorders caused by cerebral palsy are, in general, associated with language, cognitive, sensory, perceptual, and behavioral alterations, in addition to epilepsy and secondary musculoskeletal problems (Rosenbaum et al. 2007). In developed countries, CP remains the most common cause of chronic motor dysfunction in childhood, with prevalence rates of moderate and severe cases ranging between 1.5 and 2.5 per 1,000 live births (Piovesana and Cendes 2002). In developing countries, the incidence of this disorder is even greater, with indices estimating 7 cases per 1,000 live births (Diament 1996, Satow 2000, Piovesana and Cendes 2002). In Brazil, there is a lack of epidemiological studies that indicate the prevalence of CP (Rotta 2001), but studies suggest that there are about 30,000 to 40,000 new cases per year (Mancini et al. 2002).

\section{BRAIN-COMPUTER INTERFACE - BCI}

Specific papers on BCI were collected from the literature. Many were found in the medical field, some in education, but no study that mentioned people with disabilities and cerebral palsy using BCI. A survey held at the Coventry University and the Universidad Veracruzana performed by Rebolledo-Mendez and Dunwell (2009) presented a usability evaluation of the device MindSet (MS) by NeuroSky. An interesting aspect was to investigate whether the MS readings could be combined with the data generated by the user. The research group Intelligent Systems at the University of Oulu in Finland, in partnership with the Human-Computer Interaction Institute at Carnegie Mellon University, formed by Haapalainen et al. (2010), conducted a study on the evaluation of cognitive load. The group of researchers from Project LISTEN's Carnegie Mellon University, Mostow et al. (2011) showed that EEG data from the NeuroSky device could identify frequency bands that were sensitive to difficulty, and safely distinguish between easy and difficult sentences better than chance, across samples (adults and children) and different forms of 
reading (oral and silent reading). Frequency bands sensitive to difficulty and to various properties of lexical problems were identified, which suggests that they can detect transient changes in cognitive demand tasks or specific attributes of lexical access. Xu et al. (2011) from the University of California used the model of the device to develop a wearable assistive system for Falls Prevention that could detect fall risk by monitoring the EEG signals from users, releasing a warning before the actual fall took place. Crowley et al. (2010) from the University College Cork, in Ireland, conducted two psychological tests to assess the suitability of the headset to measure and categorize the level of attention and meditation of a user, while playing.

Wolpaw (2007) states that Brain-computer Interfaces $(\mathrm{BCI})$ are a fundamentally new approach to restore communication and control to people with severe motor disorders, such as Amyotrophic Lateral Sclerosis (ALS) and other spinal cord injuries and degenerative diseases. In 2007, the author stated that BCI could become an excellent assistive technology.

Yasui (2009), from the Advanced Technology Research at NTT DoCoMo, researched the biological signals and regular human behavior. This research was conducted with the BCI sensor while the user was driving a vehicle. Thus, specifically when driving a vehicle, the records showed an obvious pattern change when a mobile phone was introduced, even though the measurements were limited. This neuroscientific approach may assume a useful role in evaluating the everyday tasks of daily life, especially in matters of public concern including the risk associated with driving and talking on the phone.

During the Army Science Conferece held in Orlando in 2008, Parasuraman and Rizzo (2008), from George Mason University, presented a thorough study that revealed the importance of analyzing brain functions in order to enhance human performance in complex systems. In the book Neuroergonomics (Oxford University Press, 2008), some insights needed to design effective man-machine systems are presented. The author claims that this conception is required to understand the human mind in relation to labor and technology, and that this is the role of ergonomics. Cognitive Ergonomics is a branch of ergonomics. It is a set of factors focusing on the adjustment between the human cognitive skills and limitations in relation to machines, tasks and the environment. Guimarães (2004) argues that cognitive ergonomics is defined as the area "encompassing the perceptual, mental and motor processes." Abbad and Borges-Andrade (2004) point out that the concern of Cognitive Ergonomics is geared at the following mental processes:

1. Cognitive Domain-Knowledge, comprehension, application, analysis, synthesis and evaluation;

2. Affective Domain - Receptiveness, response, appreciation, organization and characterization;

3. Psychomotor Domain-Perception, positioning, mechanization and full domain.

The human mind can not be understood without a study of the brain, and that is the jurisdiction of the neurosciences, thus the study of brain and mind in the complex domain of work is only possible through neuroergonomics. Neuroergonomics can, therefore, provide for more effective and natural interactions between humans and technology.

Sellers et al. (2010) has published an article concerning the use of BCI by a 51 year-old person with Amyotrophic Lateral Sclerosis (ALS). The system consisted of a means of communication for a person who had lost all movement and speech.

OPERATION

- The process begins with the user's intention

- The intention to communicate or control something triggers a complex process in certain areas of the brain. 
- The activation of certain brain areas causes a potential difference of adjacent areas.

The hardware used in this project is called MindWave. It is developed by NeuroSky and works as a BCI (Brain-computer Interface). Its objective is to use the brain as a communication interface with the machine. It converts electrical brainwaves and analog processes into digital signals to make measurements available to feed the user interface of games, computers, and medical research applications.

1. Easy to use

2. Non-invasive

3. Single dry sensor

4. Allows for mobility

5. Access to both the raw data or data filtered through optimized algorithms

6. Platform open for any industry

Every interaction between neurons creates a tiny electric discharge, measured by EEG machines. By themselves, these charges are impossible to measure on the outside of the skull. However, a ruling mental state, driven by the activity of neurons collectively, created by hundreds of thousands of simultaneous discharges, can be measured. The motor control of limbs occurs at the top of the brain, for example. Vision is processed at the back of the brain. From an evolutionary point of view, these basic functions are present in most animals. Since humans have evolved, the prefrontal cortex at the front of the brain is where higher thoughts take place.

Emotions, mental states, concentration, etc., are all dominant in this area. This is the main reason for installing the main sensor in a known position NeuroSky as frontal parietal 1. Different brain states are the result of different patterns of neural interaction. These patterns are characterized by waves of different frequencies and amplitudes. As examples, the brain waves between 12 and 30 $\mathrm{Hz}$, beta waves, are associated with concentration, while waves between 8 and 12 hertz alpha waves are associated with relaxation, calm. Often overshadowing brain waves, muscle contraction is also associated with single wave patterns, referred to as EMG. It is by isolating these EMG patterns that some NeuroSky (2013) devices can detect eyes blinking.

\section{OBJECTIVES}

- Develop a study for product evaluation in order to determine whether people with cerebral palsy are able to interact with the computer;

- Compare the performance of people with cerebral palsy to the performance of healthy controls using the Brain-computer Interface MindWave by NeuroSky.

\section{Specific Objectives}

- Learn whether people with cerebral palsy can use the NeuroSky MindWave to perform a control task for a graphic element;

- Understand the emotional experience resulting from using MindWave;

- Learn whether there are differences between the use of MindWave by people with cerebral palsy, and by healthy controls;

- Understand the main limitations of MindWave when used by people with cerebral palsy.

\section{MATERIALS AND METHODS}

The research is qualitative in its approach. This research was developed with a case study design. This choice is justified by the fact that the case study is a design that allows for a multifaceted, in depth research of a single social phenomenon. Researchers worked with Observational Case Studies. Stake (1995) suggested that the object of participant observation can be the work conducted in classroom and new teaching methods. The author has suggested that the case study is the study of the particularity and complexity of a case, 
in order to understand its activities within special circumstances.

People with cerebral palsy and healthy controls were evaluated in Portugal and in Brazil. All procedures were carried out according to the Ethics Committee (CEP) of Feevale University. The committee represents the interests of research participants in their integrity and dignity and to contribute to the development of research within ethical standards. This research project was approved by CEP under number 02568312.8.0000.5348.

- The purpose of the study was explained to all participants.

- Before each game, the objective and mode of interaction was explained (Attention/ Meditation).

- Participants with CP performed the test individually, in the presence of two researchers and an Occupational Therapist from AFID, in Portugal. Healthy participants performed the test individually, in the presence of an investigator.

- In Brazil, the participants with cerebral palsy patients were receiving care at the physiotherapy outpatient clinic at Feevale University and the healthy controls were undergraduate students from the same University.

Participants experienced four games, in the following order:

1. "Burn" game

2. "Float" game

3. "MindtyAnt" game

4. "Jack Adventure" game

In the Burn game, the subject must concentrate in order to blow up a barrel. The play time is recorded, when the required level of attention is achieved, the barrel explodes. After the explosion, the barrel goes back to burning again, and so time can always be improved. Three attempts were made, and the time data for all three were recorded. Table I shows the records of the test.
TABLE I

Results of Burn game, time records.

\begin{tabular}{ccccc}
\hline \multirow{2}{*}{ Time(s) } & \multicolumn{2}{c}{ Controls } & \multicolumn{2}{c}{$\begin{array}{c}\text { People with Cerebral } \\
\text { Palsy }\end{array}$} \\
\cline { 2 - 5 } & Brazil & Portugal & Brazil & Portugal \\
\hline Mean & 38.09 & 50.57 & 41.67 & 57.23 \\
Median & 28 & 28.05 & 33 & 31.91 \\
$\begin{array}{c}\text { Standard } \\
\text { deviation }\end{array}$ & 22.79 & 60.28 & 29.9 & 41.21 \\
\hline
\end{tabular}

Performance Results in Seconds for Burn game in Brazil and Portugal, 2013. Source: The author.

Float is a game that measures levels of relaxation. Unlike Burn, here, the subject needs to be relaxed in order to achieve the goal, causing a ball to levitate the highest and for the longest time possible. After three attempts, the time and the height (in meters) of the attempts were recorded. Table II presents the time records of this test and Table III shows the records regarding the height (meditation's strength) achieved in this test.

TABLE II

Results of Float game, time records.

\begin{tabular}{ccccc}
\hline \multirow{2}{*}{ Time(s) } & \multicolumn{2}{c}{ Controls } & \multicolumn{2}{c}{$\begin{array}{c}\text { People with Cerebral } \\
\text { Palsy }\end{array}$} \\
\cline { 2 - 5 } & Brazil & Portugal & Brazil & Portugal \\
\hline Mean & 24.75 & 10.6 & 13.59 & 9.28 \\
Median & 16.33 & 7.25 & 12.67 & 4.74 \\
$\begin{array}{c}\text { Standard } \\
\text { deviation }\end{array}$ & 19.41 & 6.65 & 6.89 & 13.44 \\
\hline $\begin{array}{l}\text { Performance Results, in Seconds, for Float game in Brazil and } \\
\text { Portugal, 2013. Source: The author. }\end{array}$ &
\end{tabular}

TABLE III

Results for Float game, distance record.

\begin{tabular}{ccccc}
\hline \multirow{2}{*}{ Meters (m) } & \multicolumn{2}{c}{ Controls } & \multicolumn{2}{c}{$\begin{array}{c}\text { People with Cerebral } \\
\text { Palsy }\end{array}$} \\
\cline { 2 - 5 } & Brazil & Portugal & Brazil & Portugal \\
\hline Mean & 6.95 & 1.7 & 3.79 & 1.74 \\
Median & 4.43 & 2.66 & 2.59 & 1.4 \\
$\begin{array}{c}\text { Standard } \\
\text { deviation }\end{array}$ & 7.85 & 2.06 & 2.85 & 15.36 \\
\hline $\begin{array}{l}\text { Performance Results, in meters, for Float game in Brazil and } \\
\text { Portugal, 2013. Source: The author. }\end{array}$ &
\end{tabular}


MindtyAnt is a game in which the user focuses his or her attention levels to help an ant push a piece of food towards the nest. There are 16 stages that challenge the user's ability to concentrate, combining mind control with the use of a keyboard. For the testing, three attempts were made at the $1^{\text {st }}$ level of the game (which only uses mind control, without the keyboard), and the time was recorded). Table IV presents the records of MindtyAnt's test.

TABLE IV

Results of MindtyAnt game, time record.

\begin{tabular}{ccccc}
\hline \multirow{2}{*}{ Time(s) } & \multicolumn{2}{c}{ Controls } & \multicolumn{2}{c}{ People with Cerebral } \\
& \multicolumn{2}{c}{ Palsy } \\
\cline { 2 - 5 } & Brazil & Portugal & Brazil & Portugal \\
\hline Mean & 26.07 & 28.86 & 26.38 & 32.11 \\
Median & 25.5 & 27.5 & 25 & 27 \\
$\begin{array}{c}\text { Standard } \\
\text { deviation }\end{array}$ & 1.57 & 1.32 & 2.79 & 9.46 \\
\hline
\end{tabular}

Performance Results, in Seconds, for MindtyAnt game in Brazil and Portugal, 2013. Source: The author.

Jack's Adventure is a game in which the goal is to reforest other planets. Jack is the protagonist, who travels to other planets in his spaceship to help his alien friends tackle environmental problems, such as air pollution and sandstorms. At each new stage of the game, the levels of concentration required to make Jack plant the trees increase. In this game, the user played until they were not able to pass a level at the first attempt. The time for each level the user passed, without losing, was recorded. Table V shows the records of the Jack's Adventure test.

TABLE V

Results of Jack's Adventure game, time records.

\begin{tabular}{ccccc}
\hline \multirow{2}{*}{ Time(s) } & \multicolumn{2}{c}{ Controls } & \multicolumn{2}{c}{$\begin{array}{c}\text { People with Cerebral } \\
\text { Palsy }\end{array}$} \\
\cline { 2 - 5 } & Brazil & Portugal & Brazil & Portugal \\
\hline Mean & 24.88 & 20.54 & 30.07 & 26.99 \\
Median & 21.5 & 20 & 21 & 25.5 \\
$\begin{array}{c}\text { Standard } \\
\text { deviation }\end{array}$ & 12.15 & 3.78 & 19.62 & 3.86 \\
\hline $\begin{array}{l}\text { Performance Results, in Seconds, for Jack's Adventure game } \\
\text { in Brazil and Portugal, 2013. Source: The author. }\end{array}$ &
\end{tabular}

During the games, data on three successful attempts was collected.

Objective variables were recorded for all games:

- Time of game control (given by the game itself);

- Total time for all three successful attempts (collected with a stopwatch).

- Subjective variables were recorded for all games:

- Discomfort;

- Pain.

At the end, each participant was asked about the following subjective variables:

- Which game did you like the most?

- Which game did you like the least?

- Which was the easiest game?

- Which was the hardest game?

\section{Population}

Below, Table VI characterizes the population of the tests.

TABLE VI

Comparison of population by age.

\begin{tabular}{ccccc}
\hline \multirow{2}{*}{ Age } & \multicolumn{2}{c}{ Controls } & \multicolumn{2}{c}{$\begin{array}{c}\text { People with Cerebral } \\
\text { Palsy }\end{array}$} \\
\cline { 2 - 5 } & Brazil & Portugal & Brazil & Portugal \\
\hline Median & 25.8 & 39.5 & 11.8 & 38.5 \\
Minimum & 3 & 19 & 3 & 23 \\
Maximum & 36 & 76 & 20 & 50 \\
$\begin{array}{c}\text { Standard } \\
\text { deviation }\end{array}$ & 7.24 & 14.13 & 5.39 & 9.2 \\
\hline
\end{tabular}

Sample Population Age in Brazil and Portugal, 2013. Source: The author.

\section{DISCUSSION}

It was found that the time consumed to perform the game tasks was similar between the populations of both countries. A greater difference was found specifically for the first and second games, namely Burn and Float. Float was considered to be the 
hardest game by all participants, since it relies on the brain wave called meditation or relaxation. Meanwhile, all the other games relied on the attention brainwave. No participants reported not having enjoyed the experience. It was observed that, when attention was diverted in games that required a higher level of attention to pass a level, there was a drop in the level of attention. This shows that conducting various activities at the same time lowers the concentration levels. Thus, we agree with Yasui (2009), who conducted a survey of the BCI sensor while the user was driving a vehicle. Also, specifically when driving a vehicle, the records showed an obvious pattern change of the concentration levels when a mobile phone was introduced.

There were no significant differences found among people with cerebral palsy in the two countries and also none found between populations without cerebral palsy, based on the games Float, MindtyAnt and Jack Adventure.

In terms of physical design, the MindWave headset fits about $87.9 \%$ of the population, however, improvements can be implemented to make it more effectively adjustable for different percentiles. The experience with the use of this product was observed to be very positive in the samples studied.

The MindWave product showed that it is able to fulfill the promise it sets out to deliver, even in special populational niches, as in the case of people with cerebral palsy.

BCI devices can be great allies to adapt interfaces so they can be used by most people without the need of motion to control elements or tools.

\section{CONCLUSIONS}

BCI technology provides a way to interact with machines, products, and systems, and, as such, is of great importance to our study, since BCI already makes it possible to adapt machines, products and systems to populations with mobility difficulties in order to improve their performance, turning disabilities into mere differences in execution, but with mean performance similar to those of healthy people. On the other hand, the study of BCI ergonomics will provide data for an analysis of mental load levels in an instant and objective way. With the analysis of these new data, researchers in the area of ergonomics are able to more objectively understand the load levels that are acceptable to mental tasks, control the onset of fatigue, minimize the occurrence of errors that may result from decreased levels of attention, among other issues that may arise. Thus, we can use brain functions to design safer systems, and more efficient operations, while advancing knowledge on brain functions in relation to procedural and cognitive performance in tasks that are required by the outside world. In order to achieve these goals, the cooperation between neuroscience and ergonomics has allowed for a better understanding of the human brain and psychophysiological functions, so as to produce knowledge for the design of technologies used for work and leisure. Additionally, this cooperation allows for the discovery of new learning methodologies that enable increased performance, thereby optimizing the adaptation between technology and man.

Research in the area of neuroergonomics has been developed using non-invasive techniques for monitoring functions of the human brain that can be used to study various aspects of human behavior in relation to work and technology, with respect to mental load, visual attention, memory, motor control, automatic human interaction, and adaptive automation processes. The use of games allows for the study of how people would work in dangerous environments without putting them in danger. For example, it makes it possible to run a fatigue test, or survey the way a new technology would affect the driver or pilot in his or her particular environment, without the risk of injury. 
During the first stage of the research, at UTL in Lisbon, pre-tests were applied and it was found that people with cerebral palsy, regardless of their age, have results similar or equal to those of healthy adults. After applying the tests in Brazil, very similar results were observed. Thus, we can envision a field of study with great chances of success in the school field, as well as in the workplace. It was also found that, among the various groups of researchers from prestigious universities, there was no published research exploring the use of BCI by people with cerebral palsy.

\section{ACKNOWLEDGMENTS}

The beginning of the project was possible with the aid of CAPES, through a senior scholarship. Researcher from Coordenação de Aperfeiçoamento de Pessoal de Nível Superior (CAPES, Proc. No697212-8). CAPES Foundation, Ministry of Education of Brazil, Brasília/DF - Brazil; Technical University of Lisbon.

\section{RESUMO}

Este artigo apresenta um estudo comparativo entre pessoas com paralisia cerebral e pessoas comuns, de diferentes idades, utilizando um equipamento de Braincomputer Interface (BCI). A pesquisa é de abordagem qualitativa. Trabalhou-se com Estudo de Casos Observacionais. Foram avaliadas pessoas com paralisia cerebral e pessoas comuns em Portugal e no Brasil. O objetivo foi desenvolver um estudo para avaliação de um produto, no intuito de perceber se pessoas com paralisia cerebral podem interagir com o computador e comparar se o desempenho destas pessoas é semelhante ao desempenho de pessoas comuns ao utilizarem o interface cérebro-computador. Ao final, constatou-se que não há diferenças significativas entre pessoas com paralisia cerebral entre os dois países e também entre as populações sem paralisia cerebral (pessoas comuns).

Palavras-chave: Brain-computer Interface (BCI), paralisia cerebral, ergonomia cognitiva, interação.

\section{REFERENCES}

ABBAD GS AND BORGES-ANDRADE JE. 2004. Aprendizagem humana em organizações de trabalho. In: Zanelli JC, Borges-Andrade JE and Bastos AVB (Eds), Psicologia, organizações e trabalho no Brasil. Porto Alegre: Artmed, p. $237-275$.

BARros LA. 1994. Suporte a Ambientes Distribuídos para Aprendizagem Cooperativa. Tese (Doutorado em Engenharia de Software). Universidade Federal do Rio de Janeiro, Rio de Janeiro.

Crowley K, Sliney A, PitT I AND Murphy D. 2010. Evaluating a Brain-Computer Interface to Categorise Human Emotional Response. In: IEEE Computer Society, Advanced Learning Technologies (ICALT), 2010 IEEE $10^{\text {th }}$ International Conference Proceedings, p. 276278.

DIAMENT A. 1996. Encefalopatia crônica na infância (paralisia cerebral). In: Dianent A and Cypel A (Eds), Neurologia Infantil. $3^{\mathrm{a}}$ ed., São Paulo: Atheneu, p. 781-798.

EXECUTIVE COMMITTEE FOR THE DEFINITION OF CEREBRAL PALSY. 2007. A Report: the Definition and Classification of Cerebral Palsy April 2006. Dev Med Child Neurol 49: 8-14.

FINNIE NR. 2000. O manuseio em casa da criança com paralisia cerebral. $3^{\text {a }}$ ed., São Paulo: Manole, p. 8.

GERALIS E. 2007. Crianças com paralisia cerebral: guia para pais e educadores. $2^{\mathrm{a}}$ ed., Porto Alegre: Artmed, p. 16.

Guimarães LBM. 2004. Ergonomia Cognitiva: Produto e Produção. Porto Alegre: FEENG/UFRGS.

HaApalainen E, Kim S, Forlizzi J AND DEY A. 2010. Psycho-Physiological Measures for Assessing Cognitive Burden. In: Bardram JE and Langheinrich M (Eds), Ubicomp $<10$ Proceedings of the $12^{\text {th }}$ ACM international conference on Ubiquitous computing, p. 301310.

IEEE LEARNING TECHNOLOGY STANDARDS COMMITTEE. 2002. Draft Standard for Learning Object Metadata. New York, 2002. Available at: $<$ http://ltsc.ieee.org/wg12/files/ LOM_1484_12_1_v1_Final_Draft.pdf $>$. Accessed in: Jun 24, 2013.

MANCINI MC, FIÚZA PM, REBELO JM, MAGALHÃES LC, Coelho ZAC, Mostow J, CHANG K AND Nelson J. 2011. Toward Exploiting EEG Input in a Reading Tutor. In: Biswas G et al. (Eds), Artificial Intelligence in Education, New York: Springer Berlin Heidelberg, p. 301-310.

MUNDKUR N AND SANKAR C. 2005. Cerebral Palsy Definition, Classification, Etiology and Early Diagnosis. Indian J Pediatr 72: 865-868.

NEUROSKY. 2013. MindWave. Available at: <http://www. neurosky.com/Products/MindWave.aspx $>$. Accessed in: Jun 24, 2013. 
PAIXÃo ML, GONTIJO APAB AND FONSECA ST. 2002. Comparação do desempenho de atividades funcionais em crianças com desenvolvimento normal e crianças com paralisia cerebral. Arq Neuropsiquiatr 60: 446-452.

PARASURAMAN R AND RIZZO M. 2008. Neuroergonomics: The Brain at Work. $1^{\text {st }}$ ed., New York: Oxford University Press, p. 3.

PiovesanA AMSG AND CENDES F. 2002. Malformações Cerebrais e Displasias Corticais. In: Fonseca LF, Pianetti G and Xavier CC (Eds), Compêndio de Neurologia Infantil. $1^{\mathrm{a}}$ ed., Belo Horizonte: Medsi, p. 219-238.

REBOLLEDO-MENDEZ G AND DUNWELL I. 2009. Assessing NeuroSky's usability to detect attention levels in an assessment exercise. In: Jacko JA (Ed), Human-Computer Interaction New Trends. New York: Springer Berlin Heidelberg, p. 149-158.

RosenBAum P, PANETH N, LEVITON A, GOLDSTEIN M, BAX M, DAMIANO D, DAN B AND JACOBSSON B. 2007. A report: the definition and classification of cerebral palsy april 2006. Dev Med Child Neurol 49: 8-14.

ROTTA NT. 2001. Encefalopatia crônica da infância ou paralisia cerebral. In: Porto CC (Ed), Semiologia Médica. $4^{\text {a }}$ ed., Rio de Janeiro: Guanabara Koogan, p. 1276-1278.
SATOW SH. 2000. Paralisado cerebral: Construção da identidade na exclusão. $2^{\mathrm{a}}$ ed., São Paulo: Cabral Editora Universitária.

SCHWARTZMAN JS. 2004. Paralisia cerebral. Arquivos Brasileiros de Paralisia Cerebral 1: 4-17.

SEllers EW, TOWNSEND G, LAPALlo BK, BOULAY CB, KRUSIENSKI DJ, FRYE GE, HAUSER CK, SCHWARTZ NE, VAUGHAN TM AND WOLPAW JR. 2010. A novel P300based brain-computer interface stimulus presentation paradigm: moving beyond rows and columns. Clin Neurophysiol 121: 1109-1120.

STAKE RE. 1995. The Art of Case Study Research. London: Sage.

WOLPAW JR. 2007. Brain-computer interfaces as new brain output pathways. J Physiol 579: 613-619.

XU W, GONG F, He L AND SARRAFZADEH M. 2011. Wearable Assistive System Design for Fall Prevention. Available at: <http://www.ee.ucla.edu/ wxu/papers/conference/xuhomdss2011.pdf $>$. Accessed in: Jun 24, 2013.

YASUI Y. 2009. A Brainwave Signal Measurement and Data Processing Technique for Daily Life Applications. J Physiol Anthropol 28: 145-150. 
